\title{
Climate change and its impact on Forest Fire in the state of Himachal Pradesh and Uttarakhand states of India: Remote Sensing and GIS Analysis
}

\author{
Firoz Ahmad*, Laxmi Goparaju \\ Vindhyan Ecology and Natural History Foundation, Mirzapur, Uttar Pradesh, India. \\ *Corresponding author: adfiroz@yahoo.com
}

Received: $2^{\text {nd }}$ July, 2018

Accepted: $15^{\text {th }}$ November, 2018

\begin{abstract}
We have examined the climate and forest fire data using Remote Sensing and GIS in the state of Himachal Pradesh and Uttarakhand states of India. The significant high forest fire events were observed in district of Pauri Garhwal (22.4\%) followed by Naini Tal (16.4\%), Tehri Garhwal (8.5\%), Almora (7.7\%), Chamoli (5.8\%), Dehra Dun (4.6\%), Uttarkashi (4.3\%), Champawat (4.2\%), Haridwar (3.6\%), Una (3.4\%), Bageshwar (3.1\%), Udham Singh Nagar (2.9\%), Sirmaur (2.7\%), Solan (2.3\%), Kangra (2.1\%), Pithoragarh (1.7\%) and Shimla (1.2\%). The LULC forest category "Deciduous Broadleaf Forest" occupied 17.2\% of total forest area and retain significantly high forest fire percent equivalent to $44.7 \%$ of total forest fire events. The study revealed that $79 \%$ of forest fire incidence was found in the month of April and May. The fire frequency was found highest in the month of April (among all months) whereas it was spread over the five grids (in the count) where the fire frequencies were greater than 100. The average monthly analysis (from January to June) for maximum temperature $\left({ }^{\circ} \mathrm{C}\right)$, precipitation $(\mathrm{mm})$, solar radiation $\left(\mathrm{MJ} / \mathrm{m}^{\wedge} 2\right)$, wind velocity (meter/sec.), wet-days frequency (number of days) and evapotranspiration (mm/day) were found to be in the range of (9.90 to 26.44), (26.06 to 134.71), (11738 to 24119), (1.397 to 2.237), (1.46 to 5.12) and (3.96 to 8.46) respectively. Rapid climate/weather severities which significantly enhance the forest fire events were observed in the month of April and May. The analysis of the Pearson Correlation Coefficient (PCC) values of climate parameters showed a significant correlation with forest fire events. The analysis of predicted (2050) climate anomalies data (RCP-6) for the month of April and annual precipitation manifest the significant rise in April temperature and reduction in annual precipitation observed over large part of high forest fire grids will certainly impact adversely to the future forest fire scenario.
\end{abstract}

Key words: Forest fire, Grid analysis, Climate/Weather parameters

\section{Introduction}

The remote sensing and GIS have the ability to handle large datasets for data management/analysis and considered a powerful tool to display/ visualization of the data in various ways. They can be successfully used to detect and monitor fire spatial pattern (Ahmad \& Goparaju, 2017a; Ahmad et al., 2018b, c), fire hazard mapping (Chuvieco \& Congalton, 1989) and overcome the traditional fire records limitations (Csiszar et al., 2005; Eva \& Lambin, 1998; Flannigan \& Vonder Haar, 1986; Korontzi et al., 2006).

The climate change maneuvering the weather parameter these days and enhanced the risk of fire activity/ intensity (Harrison et al., 2010) and threatened forest ecosystems functions (Ahmad \&Goparaju, 2017b), adversely impact the human society (Bowman et al., 2009, Flannigan et al., 2009, Whitlock et al., 2010) and can gradually alter the structure, 
composition, function and ecology of forests (Kirschbaum et al., 1996; Florent et al., 2002; Donald et al., 2004).

Fire intensity, spread, and its movement mostly depend on fuel loads and its distribution pattern lying on the forest floor (Finney, 2001), moisture in fuel (Littell et al., 2009), forest tree species contain resin (NASA, 2016), local climate/weather condition and its severity, the ignition source due to human activity (Bond and van Wilgen, 1996; Flannigan et al., 2005; Moritz et al., 2005; Bradstock, 2010). These above-mentioned parameters have been found to be an important deciding factor in fire regime (Blackmarr, 1972; Wotton et al., 2010).

A large part of the Himachal Pradesh and Uttarakhand states of India is overall dominated by Evergreen Needle leaf Forest, Evergreen Broadleaf Forest and Deciduous Broadleaf Forest (Roy et al., 2015). The deciduous forests are more vulnerable to fire (FAO, 2001). The climate severity during the summer season magnifies the fire incidence is one of the major reasons for forest degradation. The forest fire events and its association to various climate/weather parameters severity have been widely studied in developed countries (Wotton et al., 2010; Tian et al., 2012), but very few studies addressed such issues in Indian region which creates a knowledge gap in research studies.

The forest fire quantification of total burnt area extent and $\mathrm{CO} 2$ emissions in India was successfully carried out by Reddy et al., 2017. Giriraj et al., 2010 identified high fire-prone zones using ATSR satellite data. Ahmad et al., 2017 analyzed the fire spatial and temporal trend and evaluated the relationship of fire events with climate/weather data. Ahmad and Goparaju, 2018 evaluated the monthly fire events in grid format during the summer period and analyzed the relationship with climate data using a statistical method such as Cramer's V coefficient (CVC).
The study has used the monthly forest fire and climate datasets for the whole state of Himachal Pradesh and Uttarakhand states of India evaluated grid wise in GIS domain towards visualization and analyzed the spatial/temporal pattern and their relationship.

The objectives of the present study are as follows: (1) Forest fire hotspot grids identification using the overall forest fire points. (2) Spatial seasonal (monthly basis) forest fire grids pattern evaluation. (3) The spatial and temporal (monthly basis) climatic data pattern evaluation. (4) Statistical analysis (Pearson Correlation Coefficient (PCC)) was executed to analyze the climatic/weather parameters association/relationship to forest fire events. (5) The predicted (2050) climate anomalies (RCP-6 Scenario) data were evaluated to understand the future forest fire scenario.

\section{Materials and Methods}

\section{The Study area}

The Himachal Pradesh and Uttarakhand states of India (Fig. 1) have latitudes $28^{\circ} 42^{\prime} \mathrm{N}$ to $33^{\circ}$ $15^{\prime} \mathrm{N}$ and longitude $75^{\circ} 35^{\prime} \mathrm{E}$ to $81^{\circ} 01^{\prime} \mathrm{E}$ and spread over an geographical area of 109,156 $\mathrm{km}^{2}$ retain the border by the states of Jammu and Kashmir, border of Tibet and Nepal to the North, Uttar Pradesh to the South, Punjab to the West, and Haryana to the South-west. Study area varies significantly in topography and lies on the southern slope of the Himalayan range, and the climate and vegetation significantly varies with elevation, from glaciers at the highest elevations to subtropical forests at the lower elevations. The highest elevations are covered by ice/rock. Below them, between 3,000 and 5,000 meters are grasslands and scrublands. Temperate coniferous forests grow just below the tree line. At 3,000 to 2,600 meters elevation, they transit to the temperate broadleaf forests, 


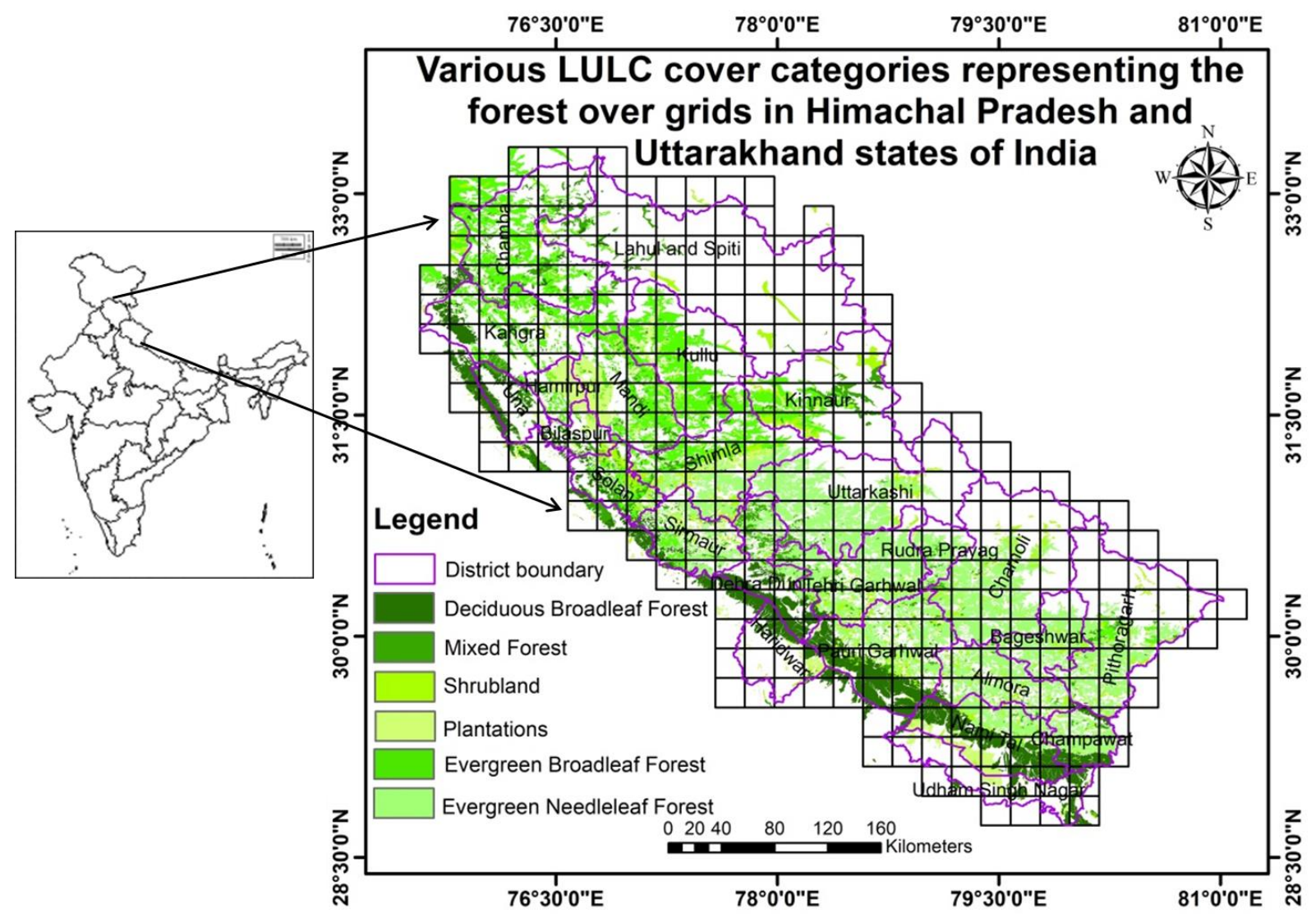

Fig.1. The location of the study area

which lie in a belt from 2,600 to 1,500 meters elevation. Below 1,500 meters elevation lie the Himalayan subtropical pine forests mixing with moist deciduous forests to lowland plane area along with the border of Uttar Pradesh, Haryana, and Punjab. Summer season starts in the month of March/April and lasts up to the month May/June whereas the monsoon arrives in the month of June onwards.

\section{Data Preprocessing and analysis}

The present study utilized the forest fire points datasets (2008 to 2016) downloaded from Forest Survey of India (FSI) website: http://fsi.nic.in/forest-fire.php (Ahmad \& Goparaju, 2018). We have utilized the land use and land cover (LULC) data (2005) representing various forest categories having the 100-meter resolution (Roy et al., 2015). The quality of classified images was evaluated based on field sample points (Roy et al., 2012). Monthly (January to July) climate datasets (maximum temperature, precipitation, solar radiation, and wind velocity) with the spatial resolution one kilometer were downloaded from the World Clim-Global Climate Data website (http://worldclim.org/version2) widely used in GIS application (Fick and Hijmans, 2017). We have used these monthly climate data and generated maps (February, March, April, May, June, and July) showing the variability (+ increase, - decrease) with respect to base month January. Additionally, we have also downloaded district wise decadal evapotranspiration and number of rainy days data (1993 to 2002) on monthly basis (January to June) from Indian Water Portal (http://www.indiawaterportal.org/met_data/). Pearson Correlation Coefficient (PCC) was used to understand the relationship of the climatic/weather parameter trend with forest 
fire incidence. We have downloaded the predicted climate datasets which were in point grid format for temperature anomaly for the month of April and annual precipitation (climate change scenario RCP-6) for the year 2050 (NCAR GIS Program. 2012). The ARC/ GIS and Erdas Imagine Software were used to analyze various datasets.

\section{Result and Discussion}

\section{Grid wise overall forest fire assessment}

We have generated the grids (12 minutes spacing) so that forest fire point and climate data can be better visualized and correlated over the study area. The total forest area within this grids was found to $42 \%$ of the total geographical area (Fig. 1). The cross comparison revealed "Deciduous Broadleaf Forest" category occupied $17.2 \%$ of total forest area and retain forest fire percent equivalent to $44.7 \%$ of total forest fire events. Similarly, the rest forest categories "Evergreen Needleleaf Forest", "Evergreen Broadleaf Forest", "Shrubland", "Plantations" and "Mixed Forest" retained $38.9 \%, 4.9 \%, 4.1 \%, 3.9 \%$ and $3.4 \%$ of total forest fire events and retained $36.5 \%, 21.8 \%, 9.1 \%, 7.3 \%$ and $8 \%$ of total forest area respectively. The similar observation was reported by FAO, 2001 where they found the deciduous forests are more susceptible to fire.

The forest fire hot spot grid map over the states of Himachal Pradesh and Uttarakhand, India is given in Fig. 2. We have also evaluated the district wise forest fire percent considering the total forest fire percent over the study area as
$100 \%$. The district wise forest fires percent are found significantly high in Pauri Garhwal (22.4\%) followed by Naini Tal (16.4\%), Tehri Garhwal (8.5\%), Almora (7.7\%), Chamoli (5.8\%), Dehra Dun (4.6\%), Uttarkashi (4.3\%), Champawat (4.2\%), Haridwar (3.6\%), Una (3.4\%), Bageshwar (3.1\%), Udham Singh Nagar (2.9\%), Sirmaur (2.7\%), Solan (2.3\%), Kangra $(2.1 \%)$, Pithoragarh $(1.7 \%)$ and Shimla (1.2\%). Rest other districts have significantly low forest fire percent (less than $1 \%)$.

Grid wise forest fire spatial and temporal trend evaluation

In this study, we have analyzed the grid wise forest fire spatial distribution pattern on monthly basis. The forest fires grid-based distribution pattern over the month of January, February, March, April, May, and June are given in Fig. 3, Fig. 4, Fig. 5, Fig. 6, Fig. 7 and Fig. 8, respectively. Table 1 shows the monthly forest fire occurrence (January to June) over the state of Himachal Pradesh and Uttarakhand to understand the seasonal forest fire trend. The forest fires events percent in the month of January, February, March, April, May, and June are found to be $0.19 \%, 1.06 \%, 7.36 \%$, $44.81 \%, 33.86 \%$, and $12.72 \%$ respectively considering total forest fire frequency between these periods as $100 \%$ (Table 1).

Around $79 \%$ of forest fire occurred in the month of April and May whereas $44.8 \%$ of forest fire events alone in the month of April. The evaluation of grid wise forest fires events in the month of January and February were found significantly low (Fig. 3a and Fig. 3b).

Tab.1. Monthly forest fire events

\begin{tabular}{ccccccc}
\hline Month & Jan. & Feb. & March & April & May & June \\
\hline $\begin{array}{c}\text { Forest fire events } \\
\text { (frequency) }\end{array}$ & 14 & 80 & 553 & 3369 & 2545 & 956 \\
Forest fire \% & 0.19 & 1.06 & 7.36 & 44.81 & 33.86 & 12.72 \\
\hline
\end{tabular}




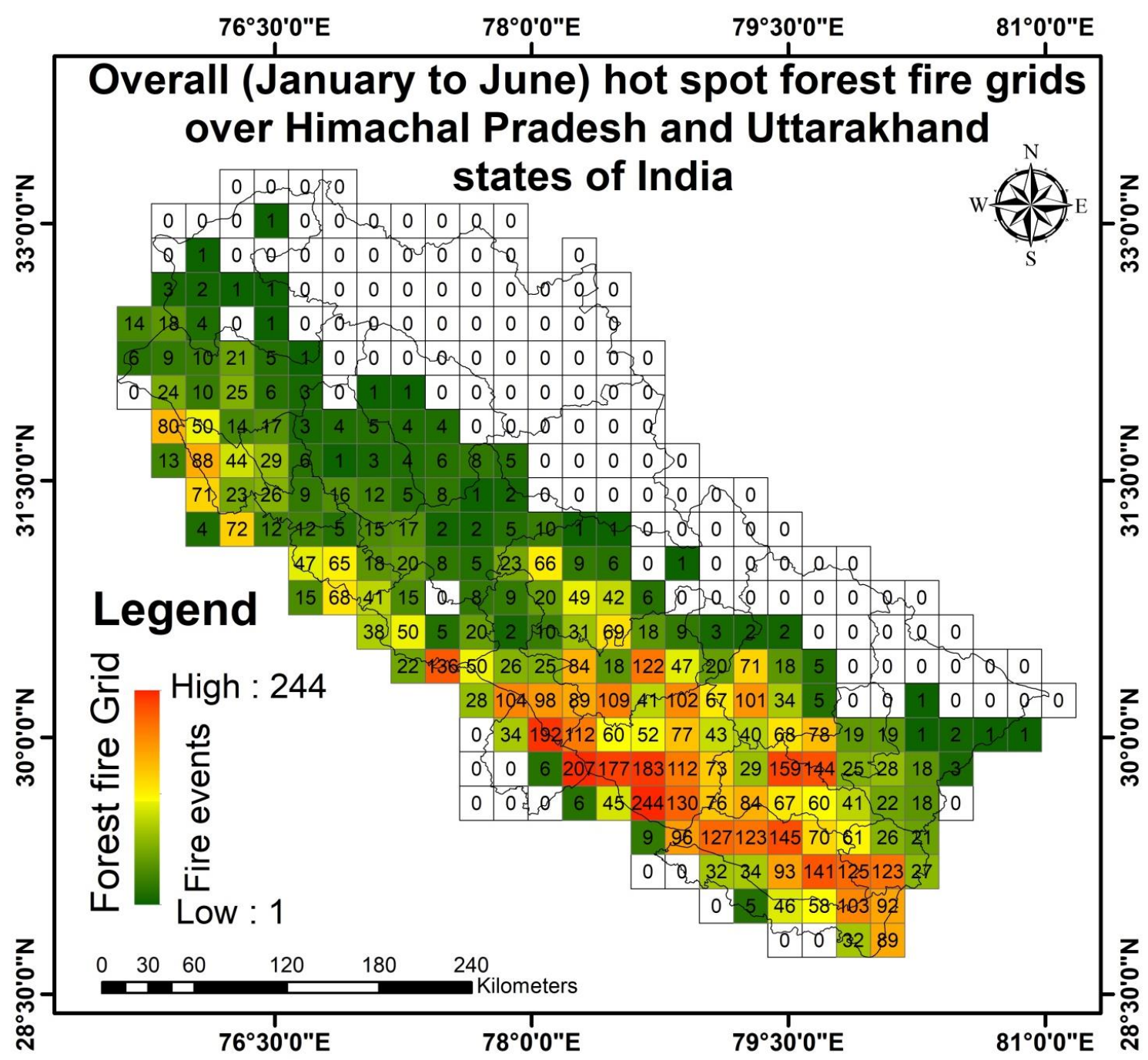

Fig.2. The overall hot spot forest fire grids over the state of Orissa

The forest fire intensified in the month of March. The total three grids (in the count) showed the fire frequency greater than equal to 20 and out of this, one grid (in the count) were found to be common where the forest fire frequency was highest in the month of January and February (Fig. 3a, Fig. 3b, and Fig. 3b). The fire frequency was further increased in the month of April and found highest among all months. In the month of April, fire events were found highest in five grids (in the count) with the fire frequency greater than 100. Similarly, in the month of May fire events were reduced and only five grids (in the count) was found with the fire frequency greater than 50 (Fig. $3 \mathrm{e})$. Furthermore, in the month of June, the forest fire events further reduced because of the active pre-monsoon weather phenomenon. Similar forest fire trend has been observed by Ahmad et al., 2017 and Ahmad \& Goparaju, 2018 in the state of Jharkhand and Orissa respectively.

\section{Climatic data evaluation}

The averages of four climate parameters (maximum temperature, precipitation, solar radiation, and wind velocity) and its variability (+ increase, - decrease) were analyzed monthly basis (February to July) with respect to base month (January) (Fig. 4, Fig. 5, Fig. 6 and Fig. $7)$. 


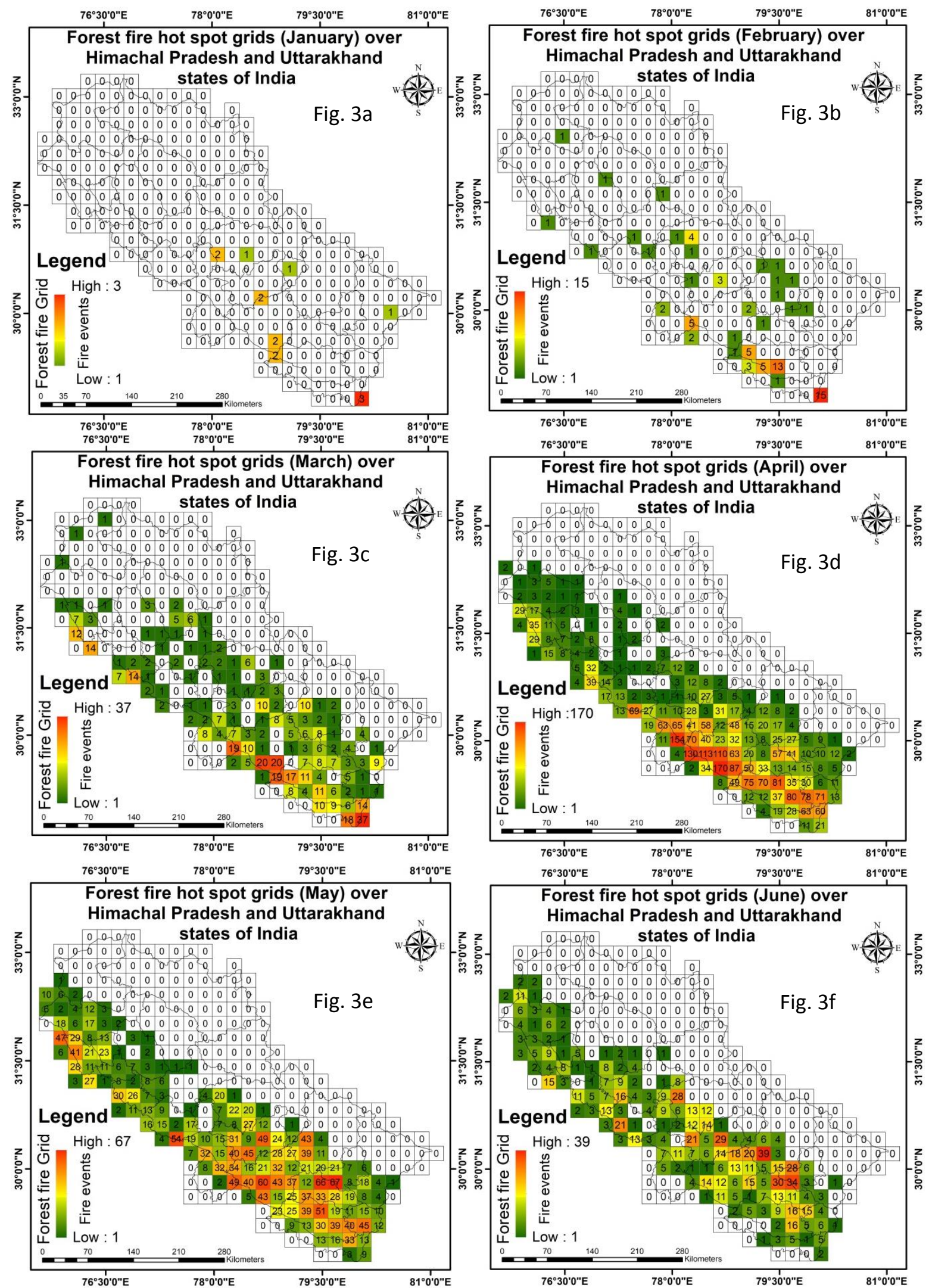

Fig.3. Monthly forest fire trend (a, b, c, d, e, f is Jan, Feb, March, April, May and June respectively) 

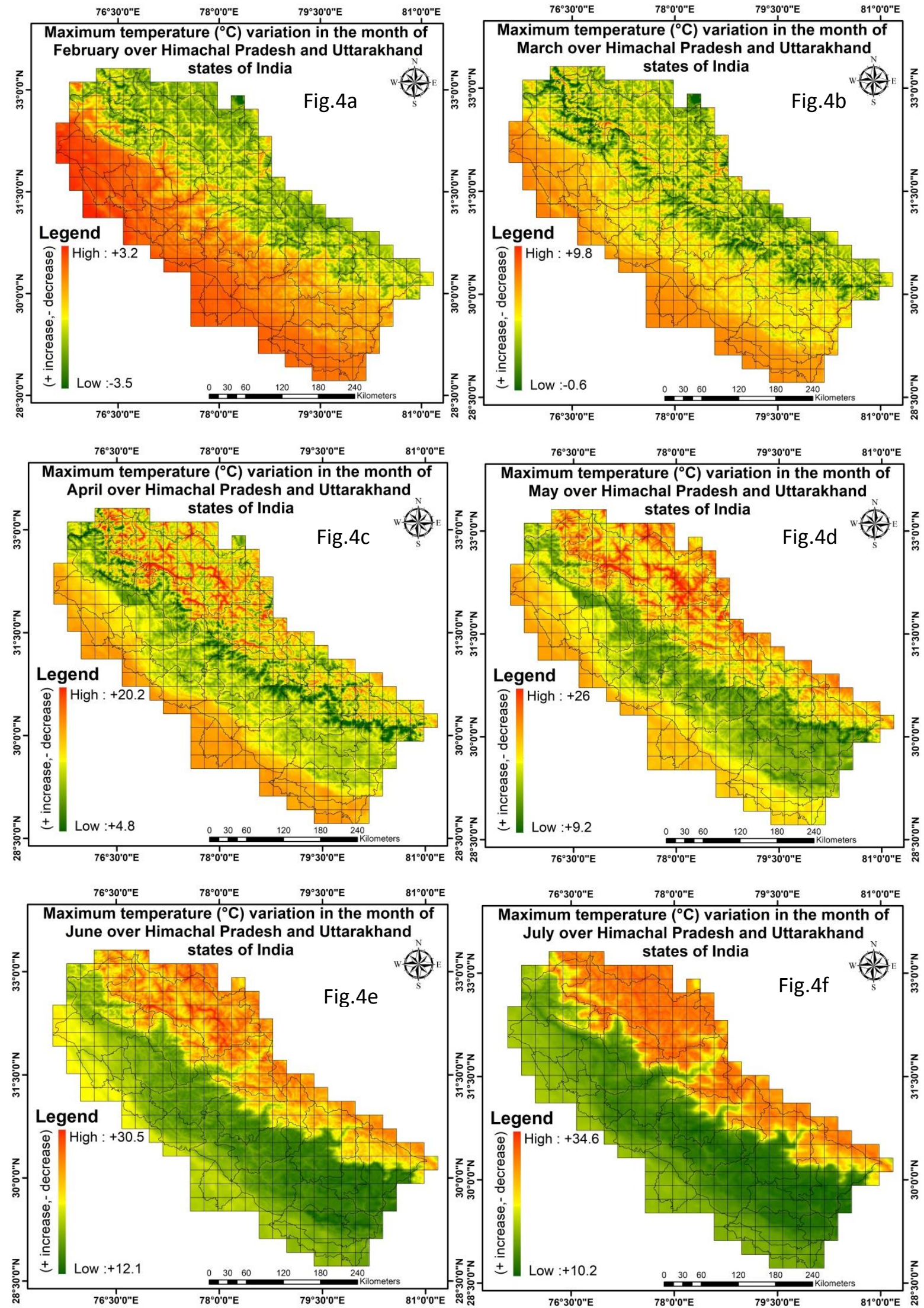

Fig.4. Monthly maximum temperature variation when compared with the base month January ( $a, b, c, d, e, f$ is Feb, March, April, May, June and July respectively). 


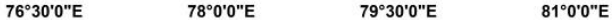
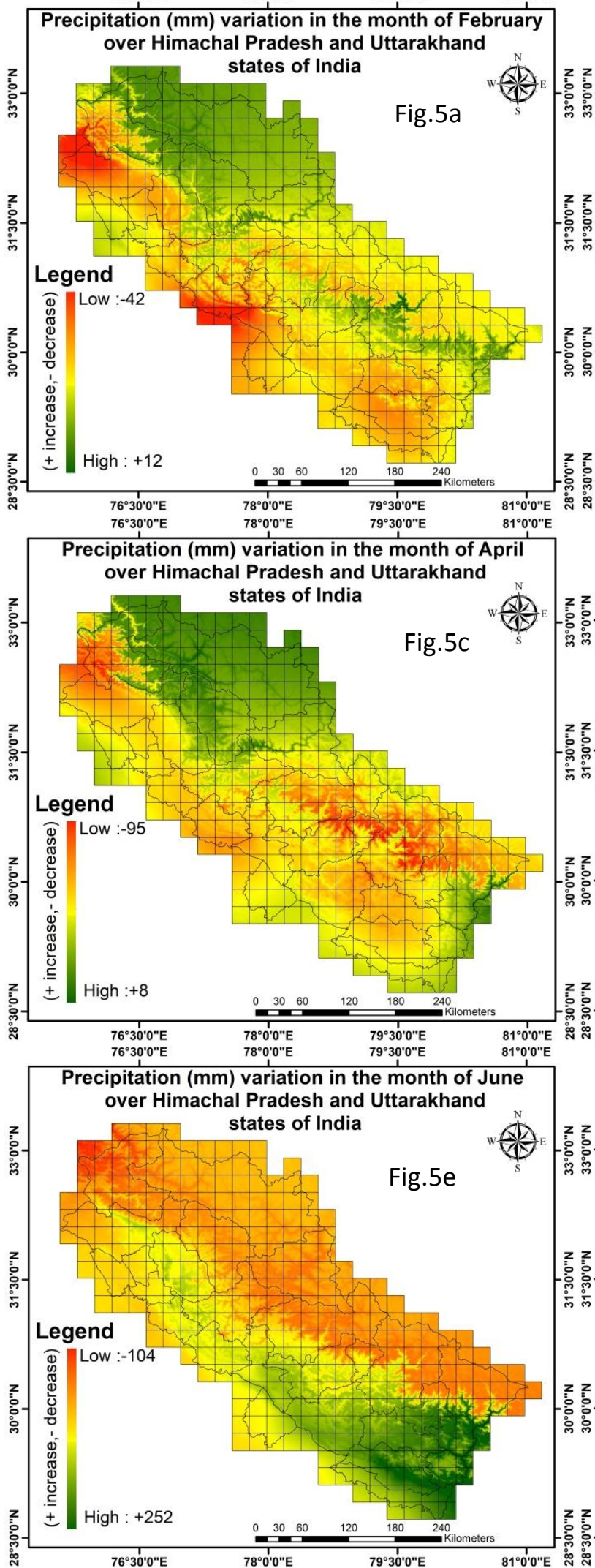

$76^{\circ} 30^{\circ} 0^{\prime \prime E}$

$78^{\circ} 0^{\prime} 0$ "E

79०30'0"E

$81^{\circ} 0^{\prime} 0 \mathrm{E}$
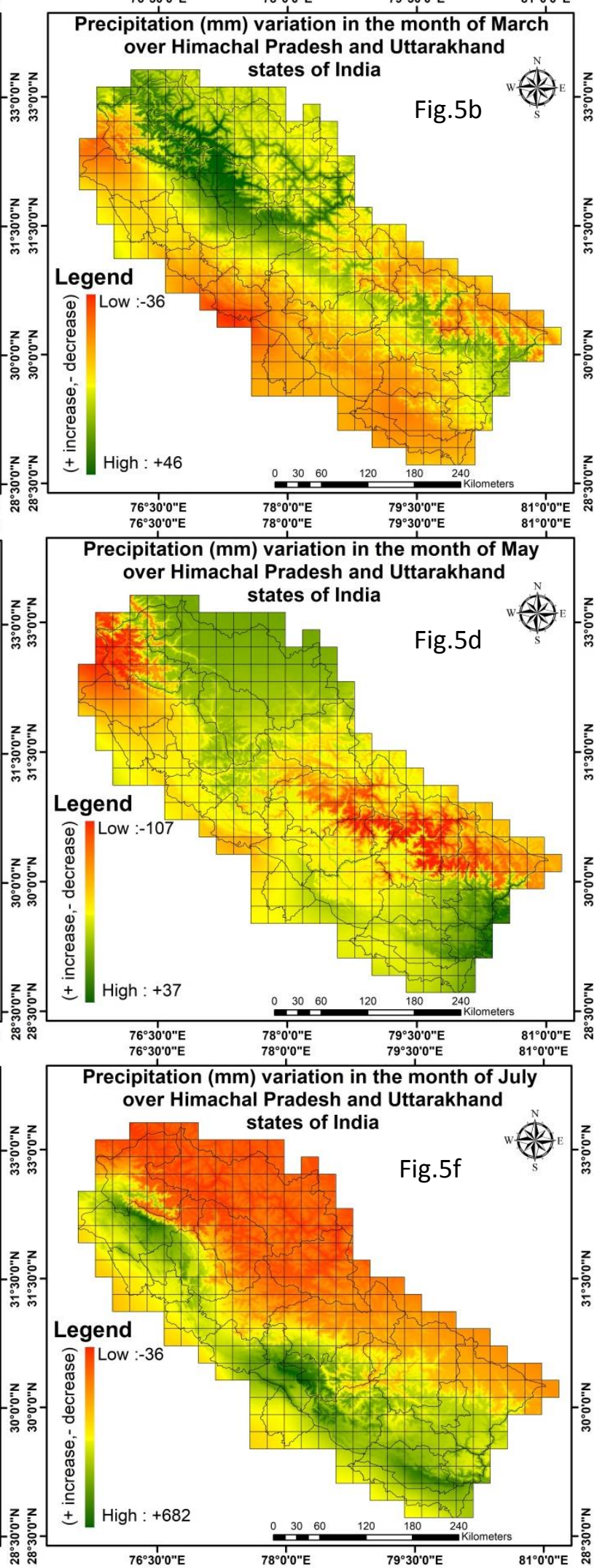

Fig.5. Monthly precipitation variation when compared with the base month January (a, b, c, d, e, f is Feb, March, April, May, June and July respectively) 

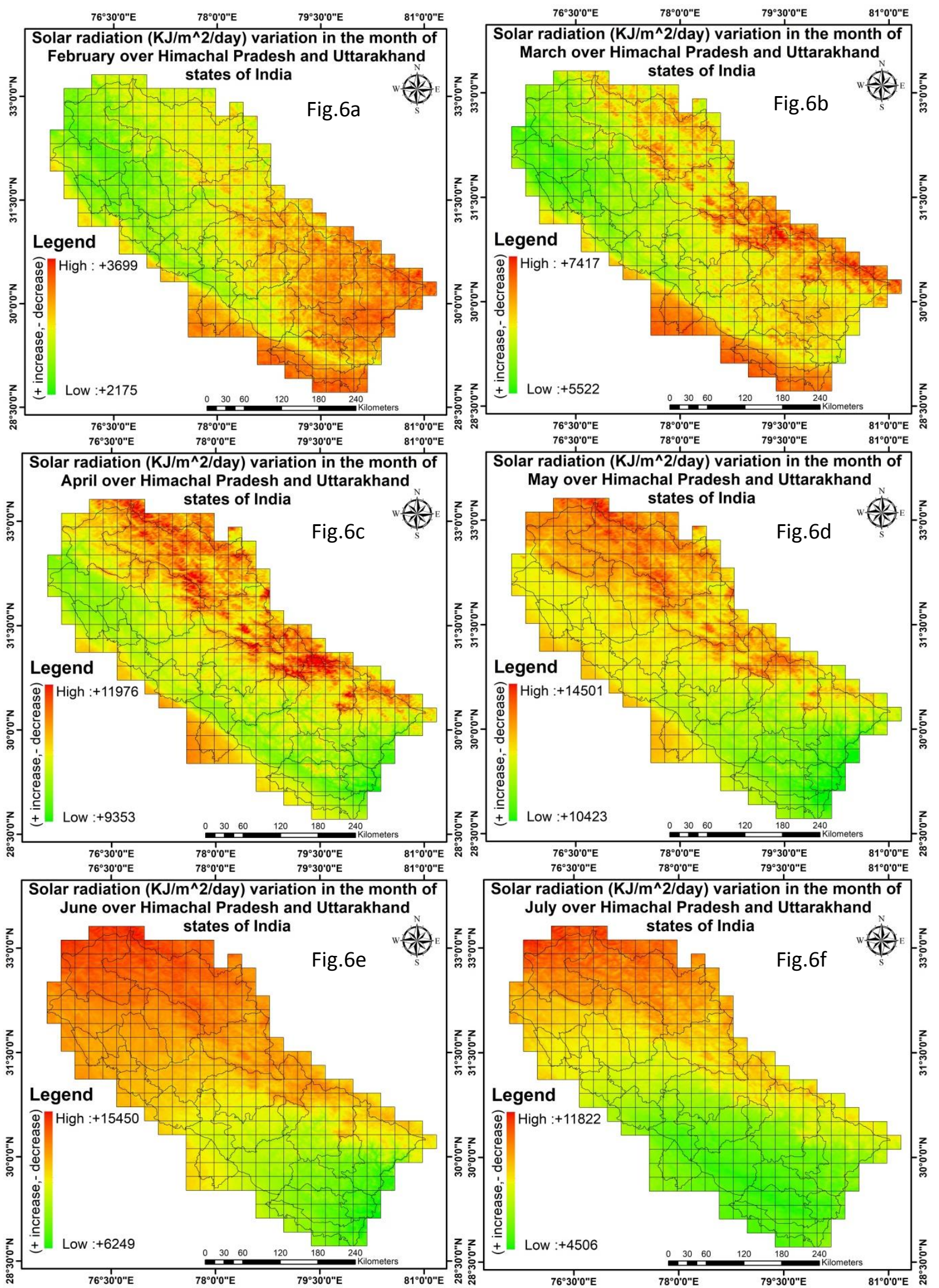

Fig.6. Monthly solar radiation variation when compared with the base month January (a, b, c, d, e, f is Feb, March, April, May, June and July respectively) 

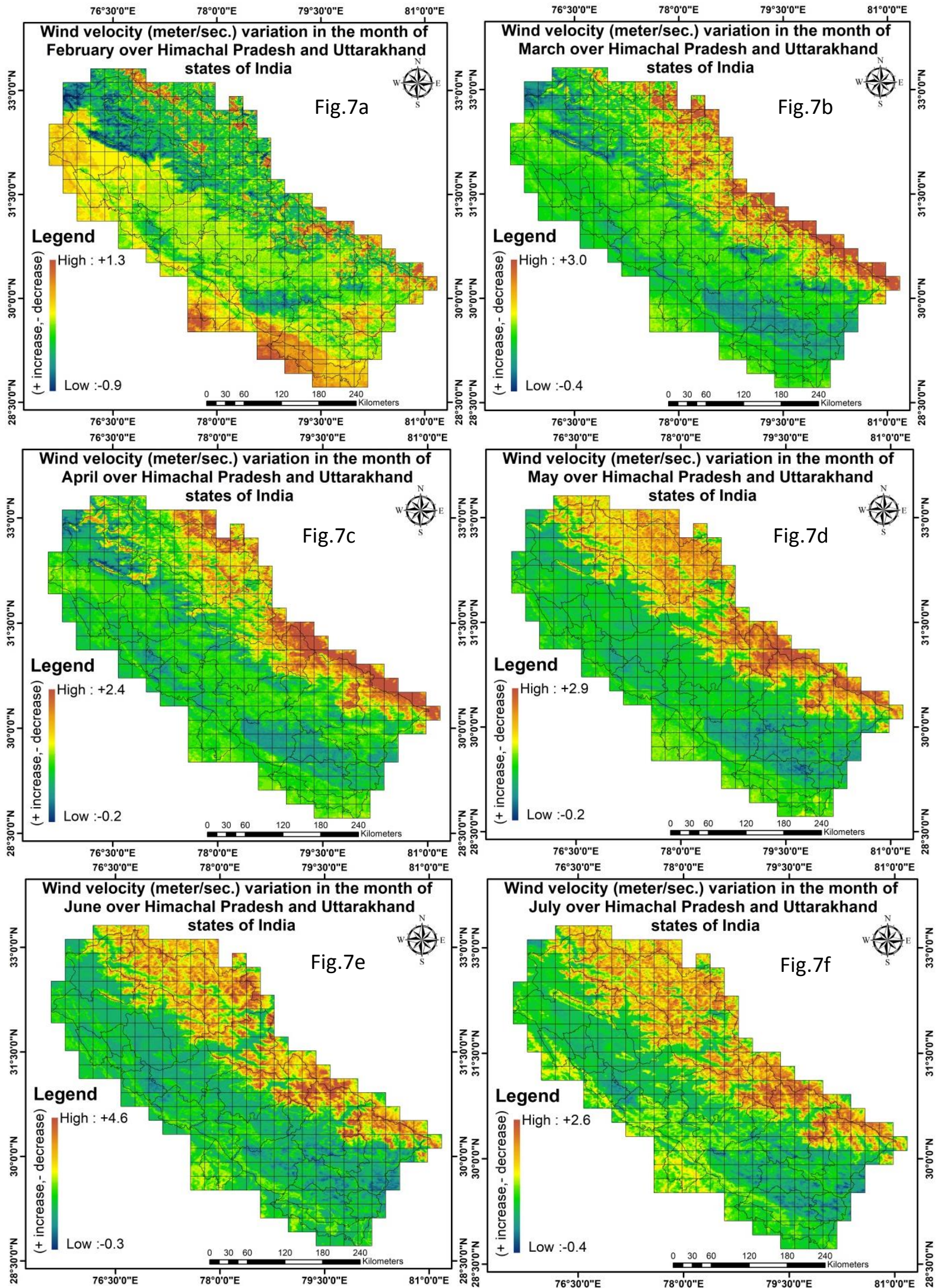

Fig.7. Monthly wind velocity variation when compared with the base month January (a, b, c, d, e, f is Feb, March, April, May, June and July respectively) 
The evaluation of maximum temperature $\left({ }^{\circ} \mathrm{C}\right)$ revealed that the temperature variation $(+$ increase, - decrease) in the month of February was roughly in between +3.2 to -3.5 whereas the significant increase was observed in the southwestern and southern portion of the grids over the plane area when compared with preceding month January (Fig. 4a). The rapid increase in temperature, observed in the month of March, was found roughly in between +9.8 to -0.6 . The significant increase was observed in Pauri Garhwal and Haridwar districts (which retain the maximum number of high forest fire events in the same month) when compared with respect to base month (January) (Fig. 4b). The temperature showed the increasing trend roughly in between +20.2 to +4.8 in the month of April over all areas (Fig. 4c). The variation of temperature in March, April, May, June, and July showed an increasing trend when compared with the base month (January) (Fig. 4c, Fig. 4d, Fig. 4e and Fig. 4f).

Analysis of precipitation $(\mathrm{mm})$ over the study area in the month of January, February, March, April, May, June, and July were found to be in the range of (7 to 173), (7 to 156), (5 to 177$),(0$ to 117$),(1$ to 98$),(4$ to 292$)$ and (25 to 748$)$ respectively. The swing (+ increase, decrease) of precipitation in the month of February, March, April, May, June, and July when compared with the base month of January were found to be in the range of $(-42$ to +12$),(-36$ to +46$),(-95$ to +8$),(-37$ to $+107),(-104$ to +252$)$ and $(-36$ to +682$)$ (Fig. 5a, Fig. 5b, Fig. 5c, Fig. 5d, Fig. 5e and Fig. 5f). The precipitation was found significantly low in several places of the majority of high forest fire areas in the month of February, March, April, and May whereas it was showing gradually increasing trend in the month of June and July.

Analysis of solar radiation $\left(\mathrm{KJ} / \mathrm{m}^{\wedge} 2 /\right.$ day $)$ in the month of January, February, March, April, May, June, and July were found to be in the range of (7341 to 13987), (10036 to 16889), (13685 to 20431), (18882 to 23857), (21696 to
25521), (19555 to 25421) and (16372 to 21081) respectively. The lowest value of solar radiation range was found increasing from the month of February to May (Fig. 6a, Fig. 6b, Fig. 6c and Fig. 6d) whereas it was gradually showing the decreasing trend in June onwards when compared with base month January (Fig. 6e and Fig. 6f).

Analysis of wind velocity (meter/sec.) over the study area in the month of January, February, March, April, May, June, and July were found to be in the range of (0.5 to 4.1), (0.4 to 5.4$),(0.8$ to 6.9$),(1$ to 5.4$),(1.3$ to 7.0$)$, (1.3 to 8.7) and (1 to 6.6) respectively. The wind velocity swing (+ increase, - decrease) in the month of February, March, April, May, June, and July when compared with the base month of January were found to be in the range of $(-0.9$ to +1.3$),(-0.4$ to +3.0$),(-0.2$ to +2.4$)$, $(-0.2$ to +2.9$),(-0.3$ to+4.6) and $(-0.4$ to +2.6$)$ (Fig. 7a, Fig. 7b, Fig. 7c, Fig. 7d, Fig. 7e and Fig. 7f). Similar climate and forest fire trend has been observed by Ahmad et al., 2018a.

The average monthly potential evapotranspiration ( $\mathrm{mm} /$ day) and wet-days frequency (number of days) of 10 highest forest fire districts were analyzed are given in Fig. 8 and Fig. 9. The potential evapotranspiration was found significantly high during forest fire period whereas the wetdays frequency was significantly low during the same period. The wet-days frequencies showed the increasing trend from April onwards (Fig. 9), found to be significantly high in the month of July due to monsoon activity. The pre and post-monsoon activity enhance the moisture significantly during the month of June and July, which brings down the potential evapotranspiration (Fig. 8) and increasing number of wet days during the same period. Such phenomenon enhances the moisture content in fuel loads (dry leaves/branches/ woods) lying in the forest floor thus reduces the chances of forest fire occurrence. The similar observation of seasonal climate variability over fire occurrences was presented by Carcaillet \& Richard 2000 and Pausas, 2004. 


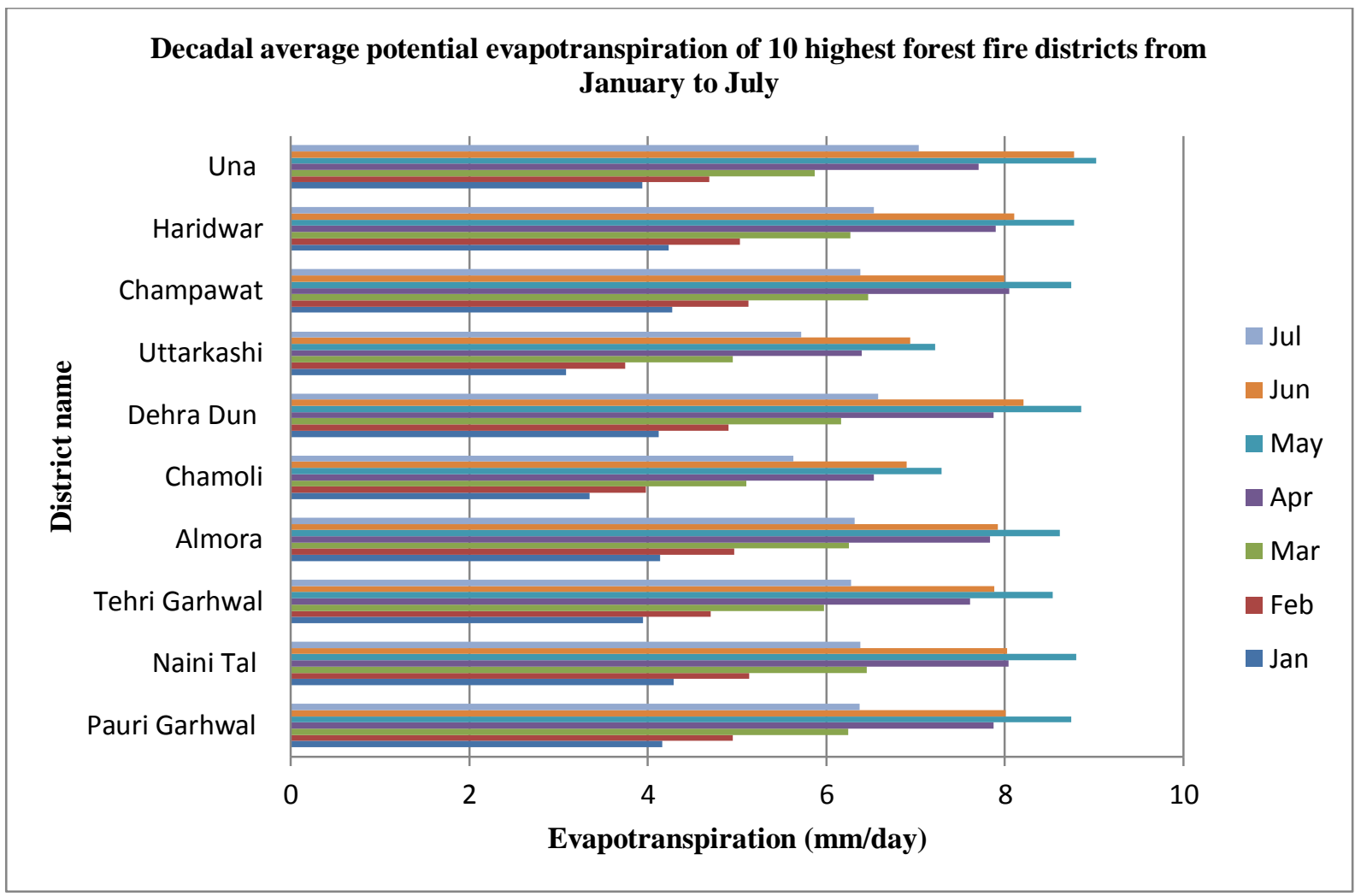

Fig.8 Decadal average monthly evapotranspiration from January to July

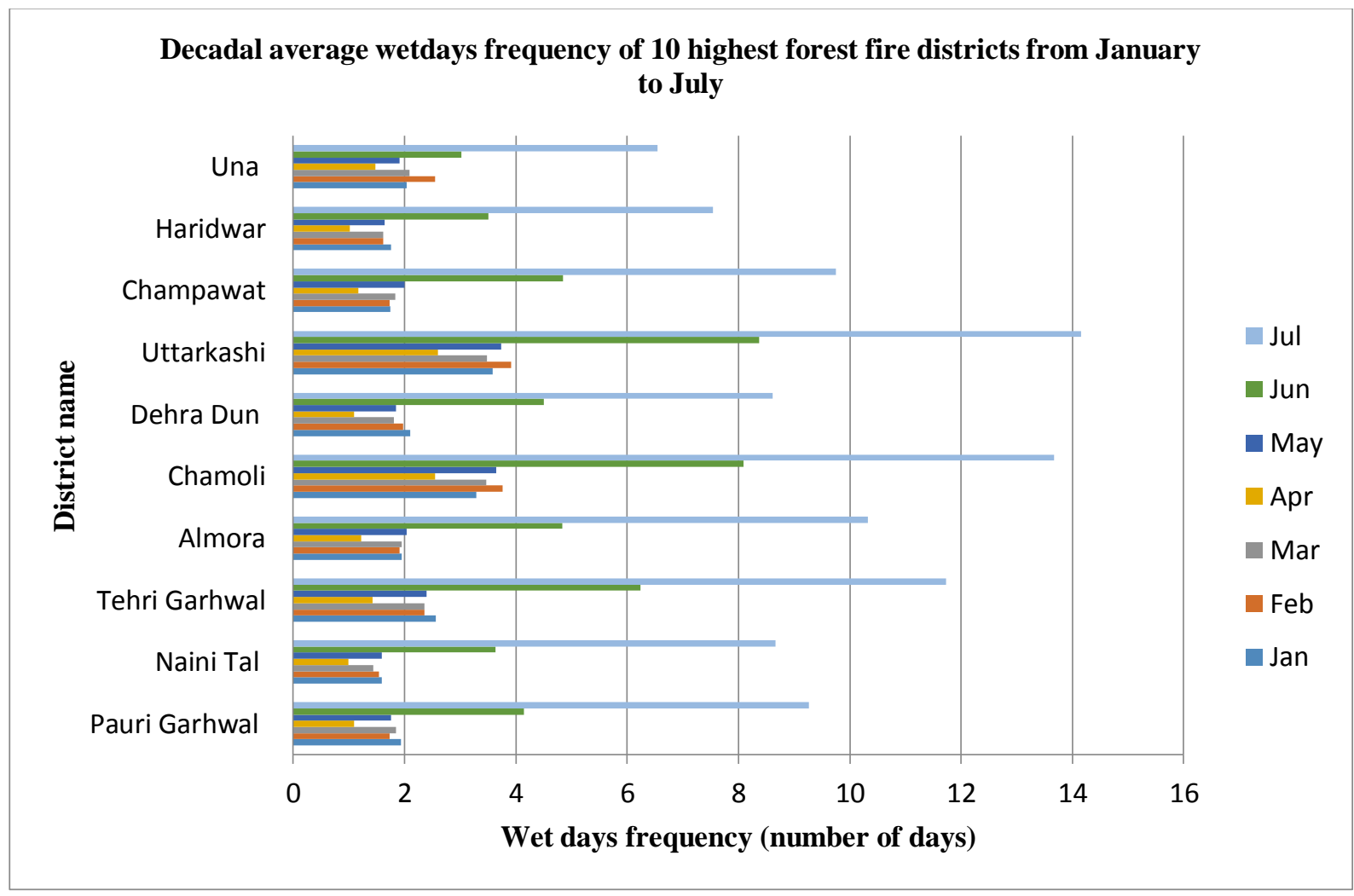

Fig.9. Decadal average monthly wet-days frequency from January to July 


\section{Statistical evaluation:}

Here we have examined the relationship of forest fire incidence with climate data using Pearson Correlation Coefficient. The average monthly climate data observation from January to June is shown in Table 2. The maximum temperature, precipitation, solar radiation, wind velocity, wet-days frequency, and evapotranspiration were found in the range of (9.90 to 26.44), (26.06 to 134.71), (11738 to 24119), (1.397 to 2.237), (1.46 to 5.12) and (3.96 to 8.46) respectively. A rapid climate/weather changes were observed which significantly enhances the forest fire events/intensity in the month of April and May. The average precipitation and wet days frequency in the month of April were found lowest (among all month) whereas they were significantly low during the month of May. The temperature increase during the month of April (highest forest fire month) was found highest $\left(5.36{ }^{\circ} \mathrm{C}\right)$ when compared with previous month whereas the solar radiation increased to $122 \%$ and evapotranspiration increased to $127 \%$ when compared with the same base month.

Here Pearson Correlation Coefficient (PCC) values of solar radiation (Tab.3), evapotranspiration, maximum temperature, and wind velocity were in decreasing order and in the range of +0.80 to +0.61 were positively (+) correlated with forest fire events. The PCC value of solar radiation was found highest (0.80) which manifest their highest relationship with forest fire events. Similarly, precipitation $(-0.52)$ and wet-days frequency $(-0.29)$ were found negatively (-) correlated with forest fire events. The significant increase in precipitation amount, not only enhance the moisture in the soil but also in the dry fuel load lying in the forest floor which greatly reduce the fuel burning capacity of the forest. The similar observation was made by Ahmad et al., 2017, while analyzing the forest fire events with the driving factor (climate parameter) for their study.

Tab.2. Monthly climate/weather data (January to June)

\begin{tabular}{ccccccc}
\hline Average climate data & Jan. & Feb. & March & April & May & June \\
\hline Maximum Temperature $\left({ }^{\circ} \mathrm{C}\right)$ & 9.90 & 11.51 & 16.00 & 21.36 & 24.87 & 26.44 \\
Precipitation $(\mathrm{mm})$ & 73.21 & 59.77 & 64.03 & 26.06 & 42.80 & 134.71 \\
Solar Radiation $\left(\mathrm{MJ} / \mathrm{m}^{\wedge} 2\right)$ & 11738.2 & 14729.9 & 18176.1 & 22228.5 & 24119.4 & 22141.8 \\
Wind velocity $(\mathrm{meter} / \mathrm{sec})$. & 1.397 & 1.479 & 1.892 & 1.958 & 2.140 & 2.237 \\
Wet days frequency (number of days) & 2.25 & 2.31 & 2.19 & 1.46 & 2.26 & 5.12 \\
Evapotranspiration (mm/day) & 3.96 & 4.73 & 5.98 & 7.58 & 8.46 & 7.88 \\
\hline
\end{tabular}

Tab.3. Pearson Correlation Coefficient (PCC) values of forest fire driving factors

\begin{tabular}{cc}
\hline Meteorological variable & Forest fire frequency \\
(Driving factors) & Pearson Correlation Coefficient (PCC) \\
\hline Maximum Temperature & +0.68 \\
Precipitation & -0.52 \\
Solar Radiation & +0.80 \\
Wind velocity & +0.61 \\
Wet days frequency & -0.29 \\
Evapotranspiration & +0.79 \\
\hline
\end{tabular}




\section{Climate anomalies and its impact on forest fire}

The forest fire intensity/events are increasing due to climate/weather severity (Ahmad et al., 2017). Fire and climate have a significant relationship due to their mutual interaction (Swetnam and Betancourt, 1990; Marlon et al., 2008; Aldersley et al., 2011). Climate change significantly maneuvering the weather parameter to an extreme can impact adversely on forest fire activity (Flannigan et al., 2000; Fried et al., 2004) contributing significantly to forest fire incidence (Stephens, 2005; Westerling et al., 2006). Study based on fire/weather modeling concept revealed that the forest fire incidence will be more intense and severe in future (Pinol et al., 1998; Wotton et al., 2010; Tian et al., 2012). Some of the studies on climate change also showed a rise in temperature (Betts, 2017; Giannakopoulos et al., 2009), reduction of rainfall pattern (Giorgi \& Lionello, 2008), decrease in number of rainy days (Kumar and Jain, 2010) an increase in drought (Sheffield \& Wood, 2008; Dai, 2011). These will influence many features of forest fire regime (Wells et al., 2004) including an increase in fire season span (Flannigan et al., 2005).

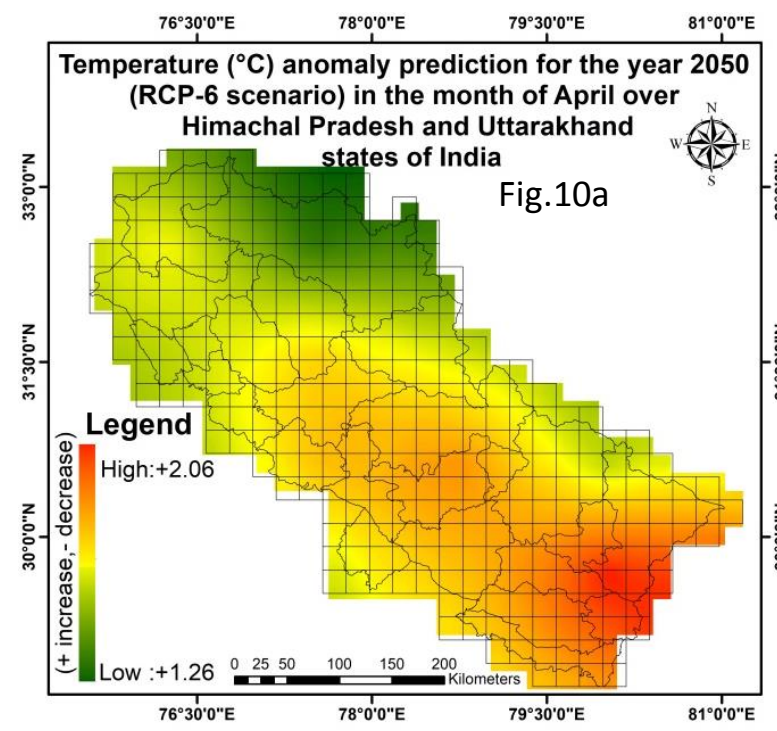

Here we have used the predicted (2050) climate anomalies data (RCP-6) for the month of April (highest forest fire month) and annual precipitation. The spatial distribution patterns of climate sets (Fig. 10) were evaluated to understand the future climate impact on the forest fire.

The increase in temperature for the month of April was found in the range of (1.26 to $2.06^{\circ} \mathrm{C}$ ). The significant rise in April temperature and reduction in annual precipitation observed over a large part of high forest fire grids (Fig. 2) will certainly impact adversely to the future forest fire scenario. Such analysis/results are a matter of serious concern for policymakers as far as the future fire prevention and its control is a concern.

\section{Conclusion}

This study has analyzed the long-term forest fire events in the state of Himachal Pradesh and Uttarakhand states of India and identified the highest forest fire grids and its monthly seasonal spatial pattern/ trend. We have evaluated the monthly trend and spatial distribution pattern of climate/weather datasets as well as future (2050) predicted April (highest forest fire month) temperature and

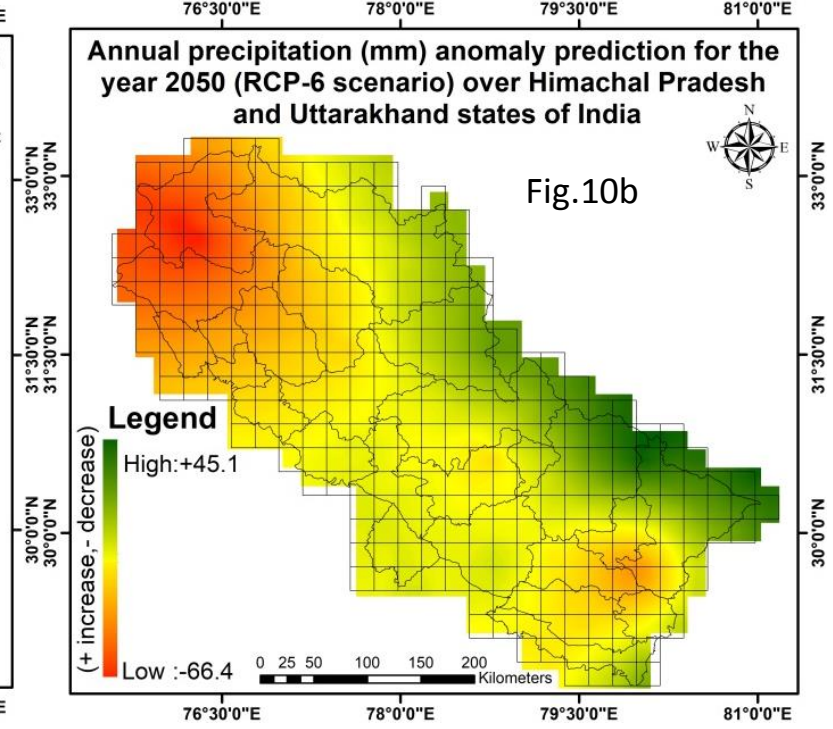

Fig.10. Climate anomalies prediction for the year 2050 over the state of Himachal Pradesh and Uttarakhand (a: April temperature, b: Annual precipitation) 
annual precipitation anomalies. The statistical method such as the Pearson Correlation Coefficient (PCC) was applied to examine the relationship/association between forest fire events and driving (climate and weather) factors.

Our analysis proved that weather severity is the strong contributor to forest fire activity thus weather forecast and alarming system are urgently required to understand the weather severity on daily basis, especially during the forest fire season. In our study, it was found some grids/ districts have significantly high forest fire events which need to be monitored frequently during the summer season. The local village committee and administration should involve the local community and other NGO groups in a fire management programme and include them as a responsible partner. There is an urgent need to upgrade/improve the effectiveness of fire prevention and control by increasing manpower/funds/equipment/apparatus/technology. The forest fire policy needs to be formulated/implemented urgently seeing the future climate change scenario.

The Remote Sensing/ GIS is a very advanced tool have the tremendous capacity to analyze various thematic datasets towards visualization of spatial/temporal paradigm and play a pivotal role in fire prevention/ control, thus largely support the policy/ decision framework.

\section{Future research scope}

There is a need of more research in the field of forest fire and its relationship with climate data /socioeconomic condition of forest dwellers/ and future climate change scenario which will give the better understanding and will sustainably fill the knowledge gap.

\section{Acknowledgements}

The authors are grateful to the Forest survey of India (FSI), WorldClim - Global Climate Data,
DIVA GIS and NCAR GIS Program for providing free download of various dataset used in the analysis.

\section{References}

Ahmad, F. \& Goparaju, L. (2017a) Geospatial Assessment of Forest Fires in Jharkhand (India). Indian Journal of Science and Technology 10(21):7. DOI: 10.17485/ijst/2017/v10i21/113215.

Ahmad, F. \& Goparaju, L. (2017b) Assessment of Threats to Forest Ecosystems Using Geospatial Technology in Jharkhand State of India. Current World Environment 12(2):11.

http://dx.doi.org/10.12944/CWE.12.2.19.

Ahmad, F. \& Goparaju, L. (2018) A Geospatial Analysis of Climate variability and its impact on Forest Fire: A case study in Orissa state of India. Spat. Inf. Res. https://doi.org/ 10.1007/s41324-018-01978

Ahmad, F., Goparaju, L. \& Qayum, A. (2018a) Himalayan forest fire characterization in relation to topography, socio-economy and meteorology parameters in Arunachal Pradesh, India Spat. Inf. Res. https://doi.org/10.1007/s41324-018-0175-1

Ahmad, F., Goparaju, L., Qayum, A. \& Quli, S.M.S. (2017) Forest fire trend analysis and effect of environmental parameters: A study in Jharkhand State of India using Geospatial Technology. World scientific news. 90(2017):31-50

Ahmad, F., Uddin, M.M.\& Goparaju, L. (2018b) Spatial analysis of Fire Characterization along with various gradients of Season, Administrative units, Vegetation, Socio economy, Topography and Future climate change: A case study of Orissa state of India. Ecological Questions 29(4):1-22.

http://dx.doi.org/10.12775/EQ.2018.027

Ahmad, F., Uddin, M.M.\& Goparaju, L. (2018c). Fire risk assessment along the 
climate, vegetation type variability over the part of Asian region: a geospatial approach Model. Earth Syst. Environ. https://doi.org/10.1007/s40808-018-0517-y Aldersley, A., Murray, S. J. \& Cornell. S. E. (2011) Global and regional analysis of climate and human drivers of wildfire. Science of the Total Environment 409:3472-3481.

Betts, A.K. (2017): Climate Change in Vermont. Vermont Climate Change Report for the Governor's Vermont Climate Action Commission. DOI:10.13140/RG.2.2.30544.81920.

Blackmarr, W.H. (1972) Moisture content influences ignitability of slash pine litter. USDA Forest Service Research Note SE173. U.S. Department of Agriculture.

Bond, W. J. \& van Wilgen, B. W. (1996) Fire and plants. Chapman and Hall, London, UK.

Bowman, D.M. et al. (2009) Fire in the earth system. Science, 324, 481-484. DOI: 10.1126/science.1163886.

Bradstock, R. A. (2010) A biogeographical model of fire regimes in Australia: current and future implications. Global Ecology and Biogeography 19:145-158.

Carcaillet, C. \& Richard, P. J. H. (2000) "Holocene changes in seasonal precipitation highlighted by fire incidence in eastern Canada," Climate Dynamics, vol. 16 (7): 549-559.

Chuvieco, E., \& Congalton, R. G. (1989). Application of remote-sensing and geographic information-systems to forest fire hazard mapping. Remote Sensing of Environment, 29, 147-159.

Csiszar, I., Denis, L., Giglio, L., Justice, C. O., \& Hewson, J. (2005). Global fire activity from two years of MODIS data. International Journal of Wildland Fire, 14, 117-130.

Dai, A. (2011): Drought under global warming: a review. WIRES Clim. Change, 2, 45-65. DOI: 10.1002/wcc.81
Donald, M., Gedalof, Z., Peterson, D.L.\& Mote, P. (2004) Climatic change, Wildfire, and Conservation. Conservation Biology 18(4): 890-902.

Eva, H. \& Lambin, E. F. (1998). Burnt area mapping in Central Africa using ATSR data. International Journal of Remote Sensing, 19, 3473-3497.

FAO (2001) Global forest fire assessment 1990-2000. FAO (Forest Resources Assessment), Rome.

Fick, S.E. and Hijmans, R.J. (2017) Worldclim 2: New 1-km spatial resolution climate surfaces for global land areas. International Journal of Climatology. http://worldclim.org/version2 (Accessed on $10^{\text {th }}$ May 2018)

Finney, M.A. (2001). Design of Regular Landscape Fuel Treatment Patterns for Modifying Fire Growth and Behavior. Forest Science 47: 219-229.

Flannigan, M. D., \& Vonder Haar, T. H. (1986). Forest-fire monitoring using NOAA satellite AVHRR. Canadian Journal of Forest Research-Revue Canadienne De Recherche Forestiere, 16, 975-982.

Flannigan, M. D., Krawchuk, M. A., de Groot, W. J., Wotton, B. M. \& Gowman. L. M. (2009) Implications of changing climate for global wildland fire. International Journal of Wildland Fire 18:483-507.

Flannigan, M. D., Stocks, B. J. \& Wotton, B. M. (2000) Climate change and forest fires, Science of the Total Environment, vol. 262(3): 221-229.

Flannigan, M.D., Logan, K.A., Amiro, B.D., Skinner, W.R. \& Stocks, B.J. (2005) Future area burned in Canada. Clim Chang 72:1-16.

Florent, M., Serge, R. \& Richard, J. (2002) Simulating climate change impacts on fire frequency and vegetation dynamics in a Mediterranean-type ecosystem. Global Change Biology 8(5): 423-437. 
Fried, J. S., Torn, M. S. \& Mills, E. (2004) "The impact of climate change on wildfire severity: a regional forecast for northern California," Climatic Change, vol. 64(1-2): 169-191.

Giannakopoulos, C., Le Sager, P., Bindi, M., Moriondo, M., Kostopoulou, E.\& Goodess, C.M. (2009) Climatic changes and associated impacts in the Mediterranean resulting from a $2 \quad{ }^{\circ} \mathrm{C}$ global warming. Glob. Planet. Chang. 68: 209224.

Giorgi, F. \& Lionello, P. (2008) Climate change projections for the Mediterranean region. Glob. Planet. Chang. 63: 90-104.

Giriraj, A., Babar, S., Jentsch, A., Sudhakar, S. \& Murthy, M. S. R. (2010) Tracking fires in India using Advanced Along Track Scanning Radiometer (A)ATSR data; Remote Sens. 2 :591-610.

Harrison, S., Marlon, J., \& Bartlein, P. (2010) Fire in the Earth System. In: Dodson J. (eds) Changing Climates, Earth Systems and Society. International Year of Planet Earth. Springer, Dordrecht.

Kirschbaum, M.U.F., Cannell, M.G.R., Cruz, R.V.O., Galinski, W. \& Cramer, W.P. (1996) Climate change impacts on forests. In: Watson RT, Zinyowera MC, Moss RH, Dokken DJ (eds) Climate change 1995. Impacts, adaptation and mitigation of climate change: Scietific-technical analyses. Cambridge University Press, Cambridge.

Korontzi, S., McCarty, J., Loboda, T., Kumar, S., \& Justice, C. (2006). Global distribution of agricultural fires in croplands from 3 years of Moderate Resolution Imaging Spectroradiometer (MODIS) data. Global Biogeochemical Cycles, 20, GB2021.

Kumar, V. \& Jain, S. K.(2010) Trends in rainfall amount and number of rainy days in river basins of India (1951-2004). Hydrol. Res. 42(4): 290-306.
Littell, J. S., McKenzie, D., L. Peterson, D.L. \& Westerling, A. L. (2009), Climate and wildfire area burned in western U.S. ecoprovinces, 1916-2003, Ecol. Appl., 19(4): 1003-1021.

Marlon, J. R., Bartlein, P. J., Carcaillet, C., Gavin, D. G., Harrison, S. P., Higuera, P. E., Joos, F., Power, M. J. \& Prentice. I. C. (2008) Climate and human influences on global biomass burning over the past two millennia. Nature Geoscience 1:697-702. 54.

Moritz, M. A., Morais, M. E., Summerell, L. A., Carlson, J. M. \& Doyle. J. (2005) Wildfires, complexity, and highly optimized tolerance. Proceedings of the National Academy of Sciences 102:1791217917.

NASA (2016) Forest Fire Numbers Rise in India in 2016. https://www.nasa.gov/imagefeature/goddard/2016/forest-fire-numbersrise-in-india-in-2016 (Accessed on $1^{\text {st }}$ February 2018)

NCAR GIS Program. (2012) Climate Change Scenarios, version 2.0. Community Climate System Model, June 2004 version 3.0.

http://www.cesm.ucar.edu/models/ccsm3.0 I was used to derive data products. NCAR/UCAR. URL: http://www.gisclimatechange.org. (Accessed on $5^{\text {th }}$ March 2018)

Pausas, J. G. (2004) Changes in fire and climate in the eastern Iberian Peninsula (Mediterranean Basin), Climatic Change, 63( 3): 337-350

Pinol, J., Terradas, J. \& Lloret, F. (1998) Climate warming, wildfire hazard, and wildfire occurrence in coastal eastern Spain. Climatic Change, 38: 345-357.

Reddy, C, S., Alekhya, V, V, L, P., Saranya, K. R. L. et al (2017) Monitoring of fire incidences in vegetation types and Protected Areas of India: Implications on 
carbon emissions. J. Earth Syst. Sci. 126: 11 DOI 10.1007/s12040-016-0791-x.

Roy, P. S., Roy, A., Joshi, P. K. et al. (2015) Land Use and Land Cover Database for India. Remote Sens. 7: 2401-2430. https://doi.org/10.3390/rs70302401

Roy, P.S., Kushwaha, S.P.S., Murthy, M.S.R. et al. (2012) Biodiversity Characterization at Landscape Level: National Assessment; Indian Institute of Remote Sensing: Dehradun, India, p. 140.

Sheffield, J. \& Wood, E.F. (2008) Projected changes in drought occurrence under future global warming from multi-model, multi scenario, IPCC AR4 simulations. Clim. Dyn. 31: 79-105.

Stephens, S. L. (2005) "Forest fire causes and extent on United States Forest Service lands," International Journal of Wildland Fire, 14(3): 213-222.

Swetnam, T. W. \& Betancourt. J. L. (1990) Fire southern oscillation relations in the southwestern United-States. Science 249:1017-1020.

Tian, X., Shu, L., Zhao, F., Wang, M. (2012) Forest fire danger changes for southwest China under future scenarios. Scientia Silvae Sinicae 48: 121-125.

Wells, N., Goddard, S. \& Hayes, M. J. (2004) A self-calibrating Palmer Drought Severity Index. J. Clim., 17(12): 2335-2351.

Westerling, A. L., Hidalgo, H. G., Cayan, D. R. \& Swetnam, T. W. (2006) Warming and earlier spring increase Western U.S. forest wildfire activity. Science, vol. 313(5789): 940-943.

Whitlock, C., Higuera, P. E., McWethy, D. B. \& Briles. C. E. (2010) Paleoecological perspectives on fire ecology: revisiting the fire-regime concept. The Open Ecology Journal 3:6-23.

Wotton, B.M., Nock, C.A. \& Flannigan, M.D. (2010) Forest fire occurrence and climate change in Canada. Int $\mathrm{J}$ Wildland Fire 19:253-271. 